\title{
Revenue Sharing Fund of Tobacco Products Excise and Economic Performance in Decentralized Era
}

\author{
Pitri Yandri ${ }^{1}$, Sutia Budi ${ }^{2}$, Yayat Sujatna ${ }^{3}$, Uki Masduki ${ }^{4}$ \\ ${ }^{1}$ Institute of Technology and Business Ahmad Dahlan, Jakarta, Indonesia \\ ${ }^{2}$ Institute of Technology and Business Ahmad Dahlan, Jakarta, Indonesia \\ ${ }^{3}$ Institute of Technology and Business Ahmad Dahlan, Jakarta, Indonesia \\ ${ }^{4}$ Institute of Technology and Business Ahmad Dahlan, Jakarta, Indonesia \\ Corresponding Author: p.yandri@gmail.com
}

\section{Article Info}

Keyword:

Fiscal

Decentralization;

Tobacco;

Economic Growth.

Kata Kunci:

Desentralisasi fiskal;

Tembakau;

Pertumbuhan

Ekonomi.

\begin{abstract}
For the regions that have tobacco farming, tobacco has economic potential for them. It means that the better the productivity of tobacco farming, the better the regional economy will be. The government has, therefore, set up the Revenue Sharing Fund of Tobacco Products Excise scheme to drive tobacco agricultural productivity in every area that produces tobacco. This study uses an econometric approach to examine the effect of DBHCHT on the regional economy, both aggregate and sectoral in Rembang Regency. Rembang Regency is known as one of the tobacco producers in Central Java. The economic sectors analyzed are the agriculture, industry, and health sectors. The results show that DBHCHT has a positive effect, both aggregate and sectoral, with varying degrees of magnitude. Further collaborations on these results are entirely presented in this article.
\end{abstract}

\begin{abstract}
Abstrak: Sektor pertanian tembakau merupakan potensi ekonomi bagi keuangan daerah. Artinya, semakin baik produktivitas pertanian tembakau di sebuah daerah penghasil tembakau, semakin baik pula perekonomiannya. Oleh karena itu pemerintah menyediakan skema Dana Bagi Hasil Cukai Hasil Tembakau dalam mendorong produktivitas pertanian tembakau di setiap daerah yang menghasilkan tembakau. Studi ini menggunakan pendekatan ekonometrik untuk menguji pengaruh DBHCHT terhadap perkonomian, baik agregat maupun sektoral, di Kabupaten Rembang yang dikenal sebagai salah satu daerah penghasil tembakau di Jawa Tengah. Sektor ekonomi yang dianalisis adalah sektor pertanian, industri, dan kesehatan. Hasil pengujian menunjukkan bahwa alokasi Dana Bagi Hasil Cukai Hasil Tembakau berpengaruh positif signifikan, baik agregat maupun sektoral dengan magnitude yang berbeda-beda. Elaborasi lebih jauh atas hasil tersebut disajikan secara lengkap dalam artikel ini.
\end{abstract}

\section{INTRODUCTION}

Regional autonomy gives full authority to every region in Indonesia to run its government outside the central authority as regulated in Law No. 32/2004, which was later revised into law. No. 23/2014 concerning Regional Government. The implementation of regional autonomy provides a great opportunity for each region to optimize and explore the potential of the region so that it can improve the welfare of its people. Thus also the dependence on the central government as one of the objectives of decentralization can be minimized. Besides, in principle, there is also fiscal decentralization, which gives authority to local governments to manage their finances independently.

The authority to regulate is also included in the case of regional financial arrangements following the law No. 33/2004, on Financial Balance between the Central Government and

\begin{tabular}{l|l}
\hline 104 & Pitri Yandri ${ }^{1}$, Sutia Budi ${ }^{2}$, Yayat Sujatna
\end{tabular}${ }^{3}$, Uki Masduki ${ }^{4}$, JGPP Vol.7, No.2 (2020): June 2020


Regional Governments. It aims that the relations between the central and regional governments run fairly and in harmony. In the context of this relationship, through law. No. 33/2004 earlier, the government provided an allocation of Revenue Sharing Funds (DBH), which functioned as an effort to overcome the vertical imbalance between the central government and regional governments by taking into account the potential of producing regions.

DBH is a fund sourced from the revenue of the State Budget (APBN), allocated to the region based on a percentage to fund regional needs in the context of decentralization. In the law. $33 / 2004$, DBH is sourced from the acquisition of taxes and the use of natural resources. DBH sourced from taxes are (1) Land and Building Tax (PBB); (2) Fees for Obtaining Land and Building Rights (BPHTB); and (3) Income Tax Article 25, and Article 29 Domestic Personal Taxpayers and Article 21 Income Tax. DBH distribution from the central government based on the principle of Based on Revenue, the intention is the distribution of DBH based on the realization of revenue in the current fiscal year (Article 23 of the Law 33/2004).

In addition to the two types of $\mathrm{DBH}$, the central government also shares state revenues from the excise tax from the regions. In theory, excise is a state levy imposed on certain goods that have specific characteristics. They are consumption needs to be controlled, its circulation needs to be monitored, its use can harm society or the environment, or its use requires the imposition of state levies for justice and balance. This regulation as stipulated in the Act. No. $11 / 1995$ concerning Excise, as amended into law. No. 39/2007 with the same subject. In that law, particularly in article 66A, paragraph 1 states that the state revenue from tobacco excise taxes made in Indonesia is distributed to provinces and districts/cities. That produces tobacco excise products by $2 \%$, which are used to fund the improvement of the quality of raw materials, industrial development, fostering social environment, socialization of excise regulations, and eradication of goods subject to illegal excise".

In Indonesia, excise is levied by the Directorate General of Customs and Excise, Ministry of Finance of the Republic of Indonesia. Accessible goods include (1) ethyl alcohol or ethanol, with no regard to the material used and the manufacturing process; (2) drinks containing any amount of ethyl alcohol, with no regard to the ingredients used and the manufacturing process, including concentrates containing ethyl alcohol; and (3) tobacco products, which include cigarettes, cigars, leaf cigarettes, sliced tobacco, and other tobacco processing products, with no regard to the materials used or substitutes or auxiliaries in their manufacture. Reading the regulation, the reference to excise law and its allocation to the regions does not refer to the fiscal decentralization law, but rather a separate law, namely the excise law.

Furthermore, in the regulatory nomenclature, especially in the context of its relationship with fiscal decentralization, and specifically concerning efforts to overcome vertical disparities, the government has devised a separate allocation fund scheme for the regions. In the case of tobacco excise, the Ministry of Finance designs its allocation scheme through the Tobacco Excise Revenue Sharing Fund (DBHCHT). DBHCHT is part of transfers to regions distributed to excise producing provinces and tobacco-producing provinces (PMK No. 222/ PMK. 07/2017).

In 2017, state revenue from tobacco excise reached Rp. 149.9 trillion. This number increased by 1,238.39\% compared to 2000, which was only Rp. 11.20 trillion (Figure.1). The average increase every year (2000-2017) reaches $66.24 \%$ per year. This increasing trend is likely to continue in 2018 because the government plans to increase tobacco product excise tax. This policy is a step to control domestic cigarette production and increase excise revenue. The increase in tobacco excise tax is estimated to be around 8.9\%, assuming economic growth in 2018 of $5.4 \%$ and inflation of $3.5 \%$. The increase is in line with the enactment of the Minister of Finance Regulation (PMK) Number 147 / PMK.010 / 2016 concerning the Third Amendment to the Minister of Finance Regulation Number 179 / PMK.011 / 2012 concerning Tobacco Product Excise Tariff since January 1, 2017. The increase in the weighted average of excise cigarettes by $10.54 \%$, where the highest tariff increase was $13.46 \%$ for the type of machine-made White Tobacco (SPM), and the lowest was 0 percent for Hand Clove Cigarette (SKT). 


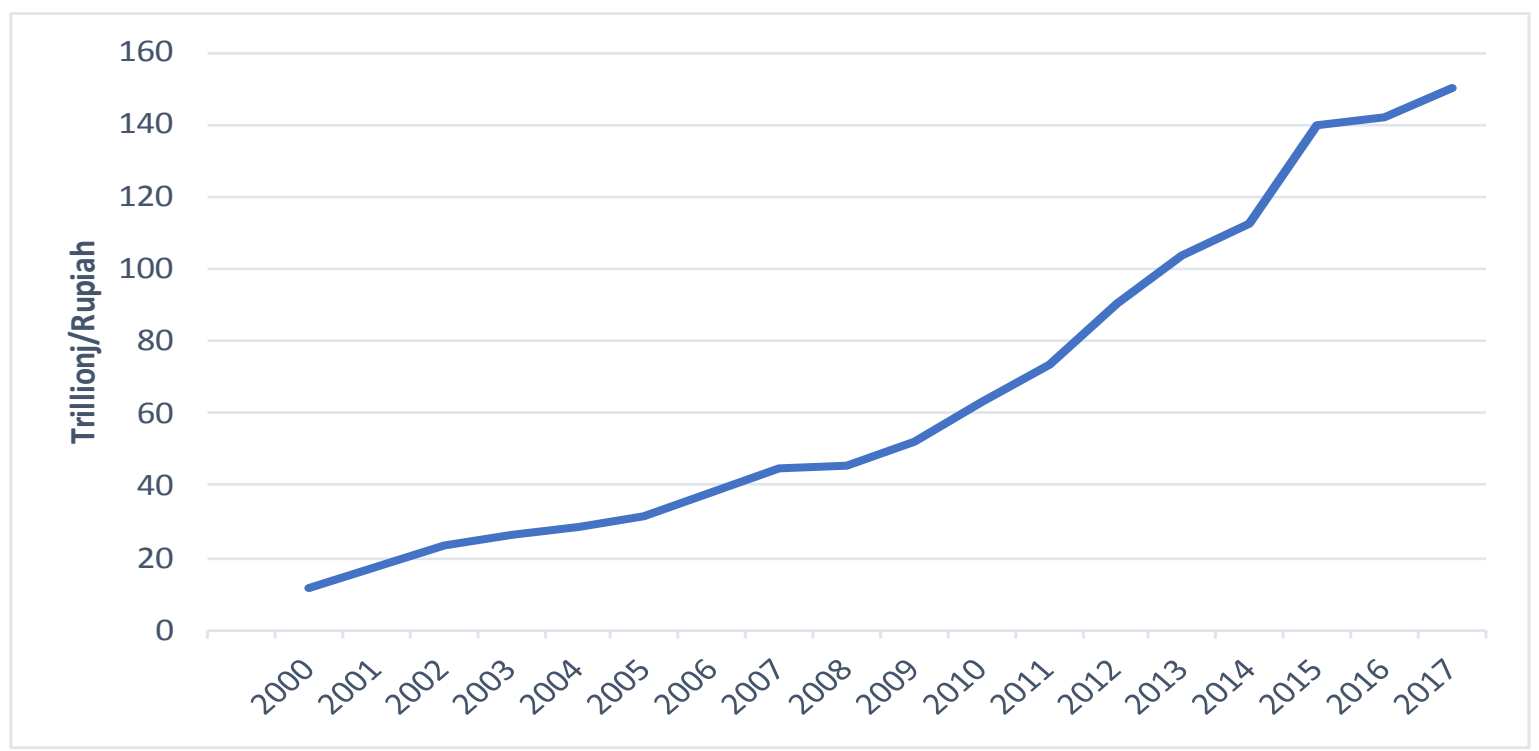

Figure.1

Development of Tobacco Excise Tax Receipt of the Republic of Indonesia 2000-2017 Source: Direktorat Jenderal Bea dan Cukai, 2019

As the Excise Law in article 66A paragraph 4 explained that "Distribution of excise sharing funds for tobacco products is carried out with the approval of the Minister, with a composition of $30 \%$ for producing provinces, $40 \%$ for producing districts/cities, and $30 \%$ for other districts/cities." In 2016, tobacco excise tax funds transferred to the regions amounted to $\mathrm{Rp} 2.85$ trillion as profit-sharing funds. In the 2017 APBNP, tobacco excise funds transferred to regions are targeted at Rp 2.95 trillion and will increase to $\mathrm{Rp} 2.96$ trillion in 2018 (DJPK Ministry of Finance of the Republic of Indonesia, 2017).

Utilization of DBHCHT itself in the Minister of Finance Regulation No. 28 of 2016 concerning Use, Monitoring, and Evaluation of Tobacco Product Profit Sharing Funds, at least $50 \%$ of DBHCHT is used to improve the quality of raw materials. Besides, funds can be used to foster industry, foster social environment, socialize provisions in the field of excise, and eradicate illegal excisable goods. In contrast, the remaining $50 \%$ is used to fund programs according to regional needs and priorities. In the meantime, the utilization of DBHCHT must also be synchronized with programs funded from the receipt of cigarette taxes, special allocation funds (DAK), general allocation funds (DAU), other revenue-sharing funds (DBH), and pure APBD expenditure (PMK No. 28/PMK.07/2016) concerning the Use, Monitoring, and Evaluation of DBHCHT.

Parallel to that, Rembang Regency is one of the districts in Central Java (Figure 2), which produces much tobacco. Of the 14 districts, almost all of them have tobacco-producing plants. Until now, there are around 7000 tobacco farmers with an area of more than 3000 hectares. Based on data from the Rembang Regency Agriculture Office, one hectare of land produces an average of 1.7 tons of tobacco. The highest tobacco-producing districts are Sulang and Sumber. These two sub-districts account for around $50 \%$ of total tobacco production in Rembang District (Table.1).

In the context of DBHCHT, of course, the tobacco farming sector is a definite potential for regional finance. It means that the better the productivity of tobacco farming, the higher the allocation of DBHCHT to be received. The greater the DBHCHT allocation, the better the fiscal capacity of the Rembang Regency Government. Fiscal capacity is a description of the financial capacity of each region reflected through general revenue of the Regional Revenue and Expenditure Budget (excluding special allocation funds, emergency funds, old loan funds, and other revenues whose use is restricted to finance certain expenditures) to finance government tasks after minus employee expenditure and is associated with the number of poor people (PMK No. 54 / PMK.07 / 2014 concerning Regional Fiscal Capacity Maps). 


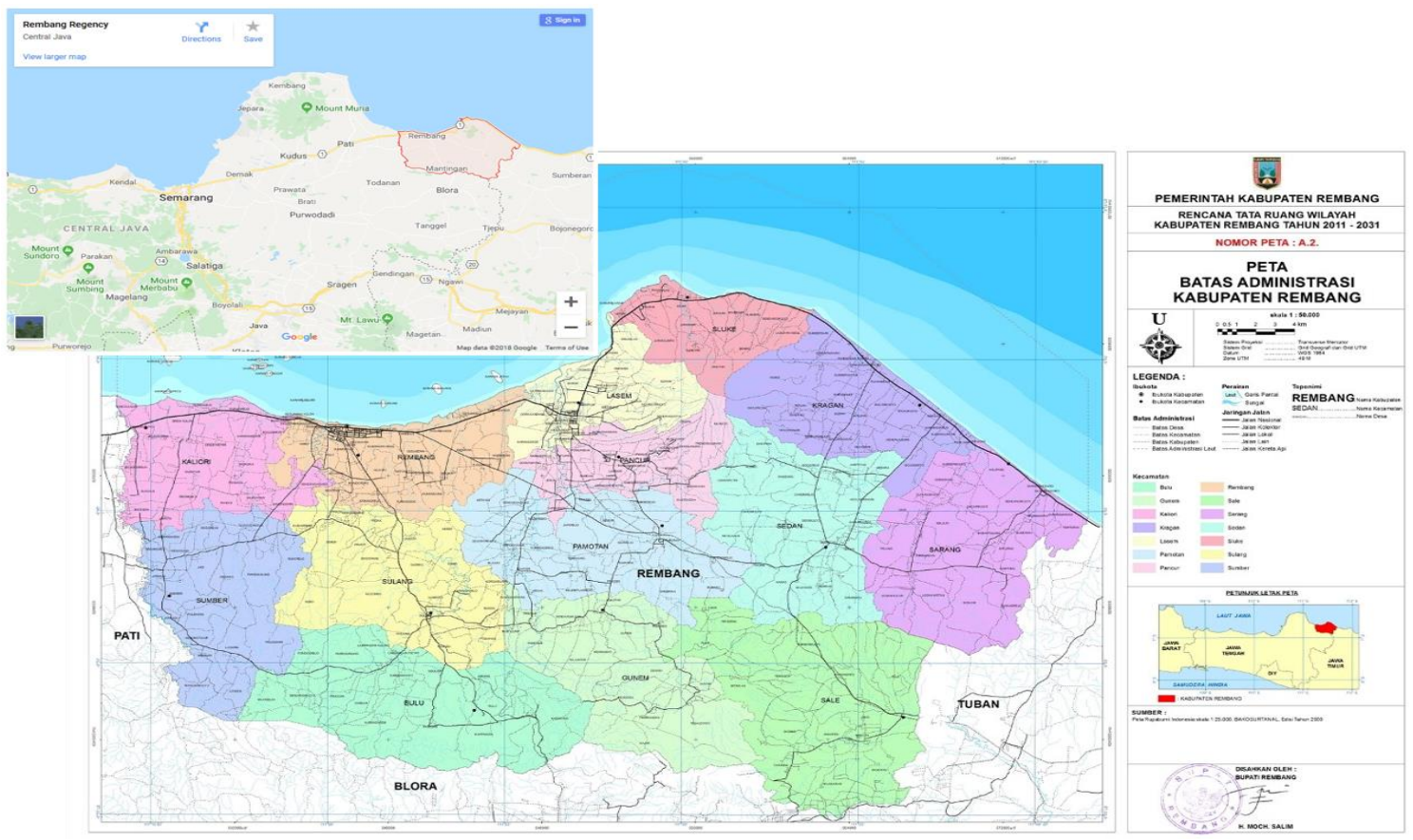

Figure.2

Location Map and Administrative Map of Rembang Regency

Source: Administrative Map Kab. Rembang: Bappeda of Rembang Regency, 2017; insert map: Google Map, 2019

Functional fiscal capacity provides opportunities for regions to finance their regional development. The opportunity to finance regional development means having a multiplier effect on the regional economy. Empirical evidence for this theory has been widely studied. Nikijuluw's study (2012), for example, states that DBH has a significant positive impact in efforts to encourage economic growth through local tax collection. The results of the same study were also concluded by Rasulong (2012) in Takalar District. Hapid et al. (2015) also found that DBH had a significant positive effect on the regional budget.

Table.1 Plant Area and Tobacco Production by District in 2016

\begin{tabular}{lrrrr}
\hline \multicolumn{1}{c}{ Sub-district } & \multicolumn{1}{c}{$\begin{array}{c}\text { Area } \\
\text { (hectare) }\end{array}$} & $\begin{array}{c}\text { Productions } \\
\text { (ton) }\end{array}$ & $\begin{array}{c}\text { Productivity } \\
\text { (kg/hectare) }\end{array}$ & Farmers (people) \\
\hline Sumber & 578 & 867 & 1500 & 578 \\
Bulu & 721 & 1082 & 1500 & 721 \\
Gunem & 420 & 630 & 1500 & 840 \\
Sale & 58 & 87 & 1500 & 60 \\
Sarang & 13 & 20 & 1500 & 24 \\
Sedan & 25 & 38 & 1500 & 56 \\
Pamotan & 340 & 510 & 1500 & 620 \\
Sulang & 1100 & 1650 & 1500 & 1200 \\
Kaliori & - & - & - & - \\
Rembang & 45 & 68 & 1500 & 62 \\
Pancur & 55 & 83 & 1500 & - \\
Kragan & - & - & - & - \\
Sluke & - & - & - & 204 \\
Lasem & 45 & 68 & 1500 & 4.437 \\
\hline \multicolumn{1}{c}{$\Sigma$} & 3.400 & 5.100 & 1.500 & \\
\hline
\end{tabular}

Source: BPS Rembang Regency, 2018

In the context of DBHCHT, many studies have been conducted in Indonesia. Sari's study (2012), for example, examines the relationship of authority between the central government and 
regional governments in implementing DBHCHT allocation programs/activities. Another study related to DBHCHT was also conducted by the World Bank (2010) with the results and recommendations on the importance of local governments to think about the need to shift the block grant to things that can ensure the farming community to move to the non-tobacco / cigarette sector. Nevertheless, the problem is that local governments often experience target misallocation in allocating DBHCHT because they consider DBHCHT as part of the cigarette factory's social responsibility (Sanjaya, 2017). In the context of the World Bank study, Hikmawati et al. (2017) even followed up with the implementation of a training program for former cigarette workers in Kudus Regency.

However, from a fiscal perspective, there are no specific studies that examine the impact of DBHCHT allocations on the economy in aggregate or sectoral terms. Though, the study is significant in the effort to formulate policy directions for the regions to perfect their regional expenditure policies. However, a recent study conducted by Ashar and Firmansyah (2015) found that the consumption of Central Java household cigarettes was statistically significantly affected by the regional income of Central Java and cigarette excise tax.

In the context of Rembang Regency, this becomes important when related to the fact that tobacco is a base sector that contributes significantly, not only to the welfare of the community at the micro-level but also to the regional economy at the macro level. Based on this description, this study aims to analyze: (1) the effect of DBHCHT allocation on the economy of Rembang Regency in the aggregate; (2) the effect of DBHCHT allocation on the development of the agricultural sector; (3) the effect of DBHCHT allocation on the development of the industrial sector; and (4) the effect of DBHCHT allocation on the development of the health sector.

\section{RESEARCH METHOD}

The research method used in this research is descriptive-quantitative. The descriptive method is used to describe the allocation of DBHCHT, Gross Regional Domestic Product (GRDP) of the agricultural sector, GRDP of the industrial sector, and GRDP of the health sector. Analysis tools in this section use the average size (mean), and the value of the percentage of growth (growth) from time to time. We use quantitative methods to analyze the influence of DBHCHT allocation in agriculture, industry, and health. Table 2 outlines the matrix of objectives, methods, and approaches used in this study.

Table.2 Matrix of Objectives, Hypotheses, Methods, Data Types, and Research Approaches

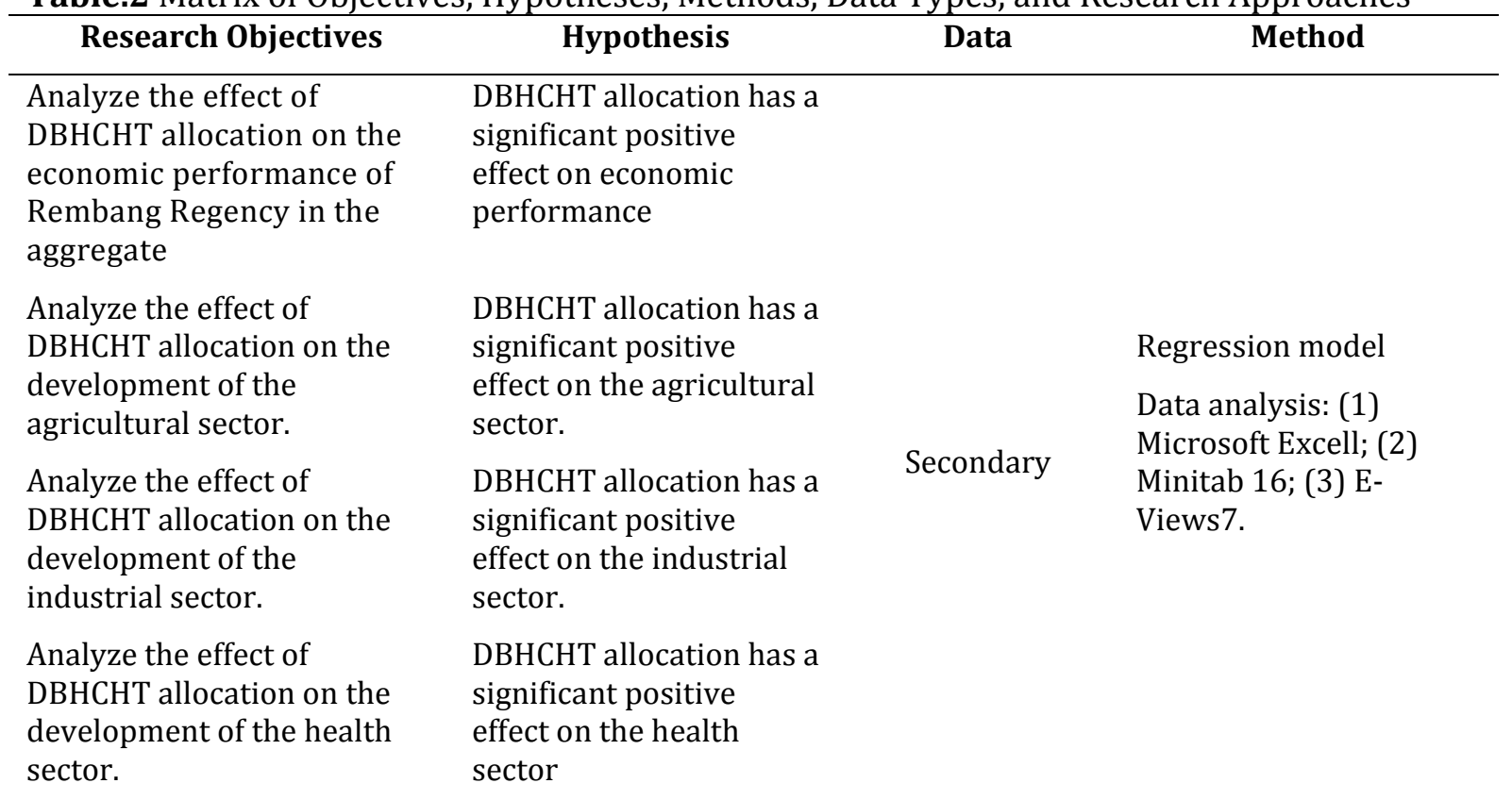

Furthermore, the type of data used is secondary data. The observed data period starts from 2008-2017. Data sources are from Rembang Regency BPS, Rembang Regency Regional 
Revenue Service, Director General of Customs and Excise, Ministry of RI, and other relevant institutions. Secondary data compilation is based on searching, selecting, recording, and categorizing data. The regression model was used to determine the effect of the DBHCHT allocation on the economy of Rembang Regency in the aggregate and sectoral sectors during the observed year, namely 2008-2017. The approach taken is ordinary least square with the model (Juanda, 2009): $Y_{t}=\alpha+\beta_{1} X_{t}+\varepsilon$ for $\mathrm{t}=1,2 \ldots$, t. Estimator model to see the influence of DBHCHT both in aggregate and sectoral, especially for agriculture, industry, and health sectors as written as follows.

$G D R P_{t}=\alpha+\beta \operatorname{lnDBHCHT} t+\varepsilon_{t}$

$\ln$ GDRPAgri $=\alpha+\beta \operatorname{lnDBHCHT} t+\varepsilon_{t}$.

$\ln$ GDRPIndustry $=\alpha+\beta \ln \mathrm{DBHCHT}_{t}+\varepsilon_{t}$

$\ln$ GDRPHealth $=\alpha+\beta \operatorname{lnDBHCHT} t+\varepsilon_{t}$.

\section{Annotation:}

$\operatorname{lnDBHCHT}_{t}$
GDRP $_{t}$
$\ln$ GDRPAgri $_{t}$
GDRPIndustry $_{t}$
GDRPHealth $_{t}$
$\alpha$
$\beta$
$\varepsilon_{t}$

RESULT AND DISCUSSION

Local governments need to increase PAD to increase economic growth. Although economic growth has not fully been able to overcome regional problems. According to Hidayati and Kuncoro (2002) and also Arsyad (2010), that economic growth is only a requirement (necessary) but not sufficient for the development process. High economic growth has little benefit in solving the problems of poverty, unemployment, and unequal distribution. The benefit of economic growth can be felt for regional problems according to Glasson (1990) is that the process of regional economic growth should no longer only focus on efforts to increase regional income but the quality of economic growth in the region. The quality of regional economic growth is related to the reduced level of disparity between developed and weak economic regions. The inequality is caused by differences in resources owned by one region and another.

For this reason, the regions need to find out which base sectors can be used as regional superior potential. According to Sumarsono (2015), this superior sector is important to know to determine the scale of priorities in development. The base sector (leading sector) is a sector that has more potential to develop compared to other sectors. This base sector will be characteristic in an area. While Tarigan (2006), divides production activities or types of work contained in an area into two, namely basic work (basic) and service work (service) or non-base sector. Base activities are exogenous activities which means they are not tied to the internal conditions of the regional economy and at the same time function to encourage the growth of other types of work while non-base sectors are activities to meet the needs of the people in the region itself.

The data down below is a description of the dynamics of economic growth in the Rembang Regency during 2008-2017 (Figure.3). The highest contribution of Rembang Regency's GRDP comes from the agriculture, forestry and fisheries sectors (30.23\%), the lowest contribution of Rembang Regency's GRDP comes from the water supply, waste and waste management sector, which is $0.05 \%$. Overall, the economy of the Rembang Regency grew by $5.15 \%$. Seven sectors grow above $10 \%$. The highest growth occurred in the health services sector and social activities $(17.90 \%)$, followed by the information and communication sector $(17.16 \%)$, the manufacturing sector (15.04\%), and the education service sector (14.86\%). The agricultural sector, which is the dominant sector in the economy of the Rembang Regency, experienced a contraction of 5.65\%. 
In the agriculture sector, the highest contribution of Rembang regency's GRDP came from the agriculture, forestry, and fisheries sectors (30.23\%), the lowest contribution of Rembang regency's GRDP came from the water supply, waste management and waste sectors, which amounted to $0.05 \%$. As one of the tobacco-producing regions in Central Java Province, Rembang Regency continues to make efforts to increase tobacco productivity. Along with that, DBHCHT acceptance continues to increase (Figure.7). The average increase from 2008 to 2017, reached $50.91 \%$ per year. BPS Rembang Regency stated, as much as $44.70 \%$ of the working-age population work in the agricultural sector, and the rest spread in the industrial sector by $9.46 \%$. It shows that the economic character of the Rembang Regency is dominated by the agricultural sector (Figure.4).

In 2017 the economy of Central Java Province was supported by the production of goods and services spread across 29 Regencies and 6 Cities. From all regencies/cities, three regencies/cities can become the largest producers of added value (NTB), namely Semarang City, Cilacap Regency, and Kudus Regency with a share of GRDP of 14.75 percent, respectively; 9.7 percent and 8.92 percent while the contribution of another regency/ city GRDP is less than 4\% on average (Figure.4).

Using equation [1-4], the information obtained from the estimation results (1) the effect of DBHCHT allocation on the economy of Rembang Regency in the aggregate; (2) the effect of DBHCHT allocation on the development of the agricultural sector; (3) the effect of DBHCHT allocation on the development of the industrial sector; and (4) the effect of DBHCHT allocation on the development of the health sector (Table.3).

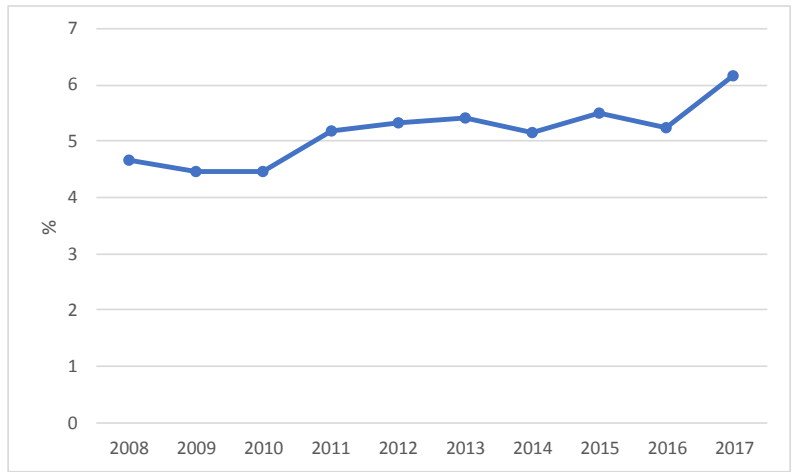

Figure.3

Economic Growth of Rembang Regency in 2008-2017 Source: BPS Rembang Regency 2018, proceeded

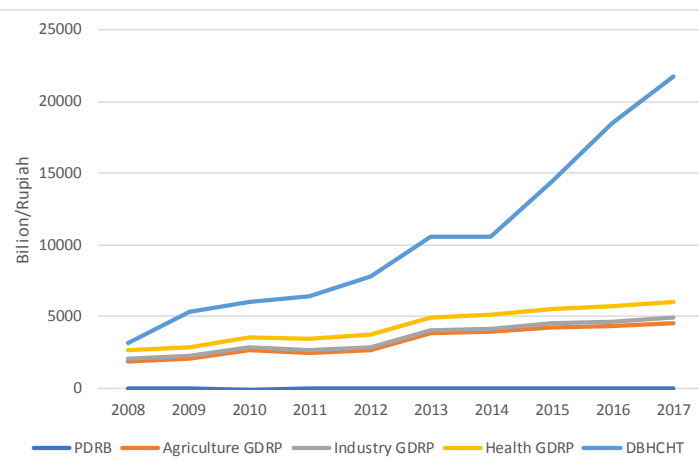

Figure.4

Dynamics of GRDP Agriculture, Industry, Health, and DBHCHT Reception District. Rembang in 2008-2017

Source: BPS Rembang Regency 2018, proceeded

Table.3 Results of Estimated Impacts of DBHCHT Allocation in Aggregate and Sectoral

\begin{tabular}{lrrrrrl}
\hline \multicolumn{1}{c}{ Variable } & Constant & Coefficient & $\begin{array}{c}\text { Standard } \\
\text { error }\end{array}$ & t-value & $\begin{array}{c}\mathrm{p}- \\
\text { value }\end{array}$ & Annotation \\
\hline $\begin{array}{l}\text { DBHCHT } \rightarrow \text { economic } \\
\text { growth }\end{array}$ & 1,9739 & 0,3815 & 0,1218 & 3,1332 & 0,0139 & Significance \\
$\begin{array}{l}\text { DBHCHT } \rightarrow \text { Agriculture } \\
\text { sector }\end{array}$ & 677,713 & 0,0327 & 0.0056 & 5,8396 & 0,0003 & Significance \\
$\begin{array}{l}\text { DBHCHT } \rightarrow \text { Industry sector } \\
\text { DBHCHT } \rightarrow \text { Health sector }\end{array}$ & 164.777 & 0,3815 & 0,1218 & 3.1332 & 0,0139 & Significance \\
\hline SBricance
\end{tabular}

Source: data proceeded, 2019

The results of the regression estimation of the effect of the DBHCHT allocation on the economic growth of the Rembang Regency are sufficient to state that the DBHCHT does have a positive impact on economic growth. Every $1 \%$ increase in the DBHCHT allocation given by the central government to Rembang Regency will encourage economic growth by $28.2 \%$, ceteris paribus (Table.3). This result is quite logical, considering the DBHCHT allocation is also one of the revenue sharing funds through the excise channel. According to its purpose, revenue sharing 
aims to improve the vertical balance between the center and the regions by taking into account the potential of producing regions.

Besides, from the perspective of macroeconomic theory, central spending to the regions through the allocation of revenue-sharing funds also states that government spending can affect economic growth in the region. In the context of decentralization, the World Bank states that it can affect economic growth indirectly. There are three ways that fiscal decentralization affects economic growth indirectly. The first argument is that decentralization will increase the efficiency of public spending so that the dynamic effect will affect economic growth. Therefore there is a positive relationship between economic growth and decentralization. Furthermore, decentralization can affect macroeconomic stability and economic growth. So we get a negative relationship between economic growth and decentralization.

The next argument is that developed countries have institutional and economic systems that are different from developing countries, so developing countries will not benefit from decentralization. It happens because the institutional arrangements in developing countries do not need to provide sub-incentives for governments to use the benefits of information in response to actions taken. Another reason is that local governments in developing countries do not have sufficient economic resources, such as government employees who are trained in managing larger budgets.

However, this study does not appear to be consistent with the results of the World Bank study. Testing of the data shows that a positive relationship occurs between the DBHCHT allocation and the level of economic growth in the Rembang Regency. Moreover, the effect of DBHCHT allocation on the economic growth of the Rembang Regency also took place positively. Reading these results, many logical arguments why the DBHCHT allocation has a positive effect on economic growth in the Rembang Regency because the economic structure of the Rembang Regency is dominated by the agricultural sector, where the agricultural sector is dominated more by tobacco plants.

The logical flow transmission mechanism occurs because: first, people who produce tobacco plants are required to pay tobacco excise. It stated in the Regulation of the Minister of Finance of the Republic of Indonesia Number 146/PMK.010/2017 concerning Tobacco Product Excise Tariff. The regulation states that the results of tobacco management are subject to excise, including other processing results, namely (a) tobacco extracts and essences, (b) molasses tobacco; (c) snuff tobacco; and (d) chewing tobacco.

Second, the tobacco excise yield is then entered into the state treasury (in this case, the central government). Third, the central government calculates revenue from tobacco excise and then allocates it to producing regions. Fourth, the results of the allocation will then be used by producing regions for spending: (a) improving the quality of raw materials; (b) industrial development; and (c) social environment development (PMK No. 222 / PMK.07 / 2017). In the medium term, spending on these three components will, in turn, produce a side effect in the form of higher economic growth through increased excitement and stretching of tobacco farming.

Meanwhile, every increase of Rp. 1 DBHCHT allocation given by the central government to the Rembang Regency will encourage an increase in the GRDP of the agricultural sector by Rp. 17.97, ceteris paribus (Table 3). This coefficient value is higher than the other sectors studied in this study. The only logical interpretation of this is because Rembang Regency is a tobaccoproducing area. Of the 14 districts, almost all of them have tobacco-producing plants. Until now, there are around 7000 tobacco farmers with an area of more than 3000 hectares. Based on data from the Rembang Regency Agriculture Office, one hectare of land produces an average of 1.7 tons of tobacco. The highest tobacco-producing districts are Sulang and Sumber. These two districts contribute around $50 \%$ of the total tobacco production in Rembang Regency. Also, when viewed from the workforce structure, almost all workers of working age work in the agricultural sector (Table.4).

Of course, the DBHCHT allocation will have a positive impact on the agricultural sector. The logical transmission process why that can happen because in PMK No. 222 / PMK.07 / 2017 states that the DBHCHT allocation is used to (a) improve the quality of raw materials; (b) industrial development; and (c) fostering the social environment. Policies in the form of programs/activities in the agricultural sector that lead to these three actions will ultimately increase the capacity/competence of farmers, which with increased capacity/potential, will 
increase their productivity. Increased productivity will, in turn, increase the agricultural sector's GRDP in Rembang Regency.

Table.4 Rembang Regency Population Aged 15 Years and Over Who Worked During the Last Week According to Main Employment, 2011-2015

\begin{tabular}{lrrrrr}
\hline \multicolumn{1}{c}{ Main Job Fields } & \multicolumn{5}{c}{ Year } \\
\cline { 2 - 6 } & \multicolumn{1}{c}{$\mathbf{2 0 1 1}$} & $\mathbf{2 0 1 2}$ & \multicolumn{1}{c}{$\mathbf{2 0 1 3}$} & \multicolumn{1}{c}{$\mathbf{2 0 1 4}$} & $\mathbf{2 0 1 5}$ \\
\hline Agriculture, forestry, hunting, and fisheries & 154.789 & 141.031 & 151.079 & 150.364 & 137.048 \\
Processing industry & 30.941 & 36.322 & 18.541 & 22.669 & 28.967 \\
Big trade, retail, restaurants, and hotels & 57.004 & 59.481 & 62.547 & 54.324 & 61.299 \\
Public services & 41.968 & 48.140 & 56.220 & 34.530 & 39.297 \\
Others & 36.045 & 39.230 & 31.954 & 43.393 & 39.499 \\
\hline Amount & 320.747 & 324.204 & 320.341 & 305.280 & 306.110 \\
\hline
\end{tabular}

Source: BPS Rembang Regency, 2017

Based on employment in 2015 of all population aged 15 years and over who worked there were $44.70 \%$ who worked in the agricultural sector, while those working in the industrial sector amounted to $9.46 \%$ (Table.4). This workforce structure seems to answer the reasons why the DBHCHT coefficient is positive for the GRDP of the industrial sector. The DBHCHT coefficient of $23.4 \%$ can be interpreted that every 1\% increase in the DBHCHT allocation can encourage the growth of the industrial sector in the Rembang Regency by $23.4 \%$, ceteris paribus (Table 3 ).

In this context, it seems that DBHCHT allocations have two main ways of 'influencing' the industrial sector's GRDP. First, the direct influence through public spending spent by the Rembang Regency Government in managing this sector for better performance. Government expenditure or consumption is the government's budget to carry out its expenditure in the context of purchasing goods and services intended for the benefit of the community and running government organizations. In Indonesia, in government spending, there are two categories of expenditure, namely routine expenditure and development expenditure. The construction expenditure is, for example, building roads, building schools while routine expenses include expenditures to pay salaries for government employees and others to finance government organizations.

Second, indirect influence. Indirect effects occur through the triggering process (triggers). In this case, DBHCHT acts as a trigger for the movement of the industrial sector in the Rembang Regency. The logical flow of the transmission process occurs through a multiplier effect mechanism after the Government of Rembang Regency spends the DBHCHT allocation. Besides allocating the DBHCHT scheme to increase agricultural capacity, especially tobacco farming, it is also allocated for infrastructures such as infrastructure that can help improve the performance of the industrial sector, especially since the industry has a direct link with the tobacco derivative industries such as cigarettes and others.

The results of the regression estimation of the effect of DBHCHT allocation on health sector GRDP in Rembang Regency are sufficient to state that DBHCHT does indeed have a positive impact on the growth of the health sector GRDP. It has been explained that every $1 \%$ increase in the DBHCHT allocation given by the central government to Rembang Regency will encourage the growth of the health sector GRDP by $18.9 \%$, ceteris paribus (Table 3 ).

In the context of DBHCHT, according to Pose et al., (2007), there are many kinds of literature which state that fiscal decentralization provides a significant change in welfare and economic benefits. He further stated that local governments (assuming they are closer to the people) are more capable of making policies that determine the public goods needed in their regions. In this context, this study succeeded in proving the theory that government expenditure or consumption is a government budget to carry out its expenditure in the context of purchasing goods and services intended for the benefit of the community and running government organizations. BPS data from Rembang Regency noted that the highest growth occurred in the health services sector and social activities (17.90\%), followed by the information and communication sector $(17.16 \%)$, the manufacturing industry sector $(15.04 \%)$ and the education service sector $(14,86 \%)$. The agricultural sector, which is the dominant sector in the economy of the Rembang Regency, experienced a contraction of 5.65\%. 


\section{CONCLUSION}

The tobacco farming sector is a definite potential for regional finance. That is, the better the productivity of tobacco farming in a tobacco-producing area, the better the economy. Therefore the government provides a DBHCHT scheme to encourage tobacco farming productivity. This study examines the effect of DBHCHT on the economy, both aggregate and sectoral, especially in Rembang Regency, which is known as one of the tobacco-producing regions in Central Java. The test results show that the DBHCHT allocation has a positive effect, both aggregate and sectoral, with different magnitudes.

A critical suggestion/recommendation for the results of this study is that the DBHCHT allocation from the central government to regional governments is highly dependent on the productivity of tobacco farming. The higher the productivity of tobacco farming in an area, the higher the allocation. Reading this information, of course, the policy agenda in the form of programs/activities that can increase the productivity of tobacco farming becomes very necessary. Also, DBHCHT obtained by Rembang Regency is aimed to target the program/activity as far as possible as stated in PMK No. 222 / PMK.07 / 2017, namely: (a) improving the quality of raw materials; (b) industrial development; and (c) fostering the social environment.

\section{ACKNOWLEDGMENT}

This research is a part of the Monitoring and Evaluation Report on the Implementation of Tobacco Excise Profit Sharing Funds in the Economic Administration Section of the Rembang Regency Regional Secretariat in 2018. The researcher would like to thank the research funding for this activity at the agency concerned.

\section{REFERENCE}

Arsyad, L. (2010). Ekonomi Pembangunan, Edisi Kelima. Yogyakarta: YUPP STIE YKPN

Ashar, F., dan Firmansyah (2015), Peningkatan Tarif Cukai Rokok Dan Dampaknya Terhadap Perekonomian Dan Pendapatan Sektoral Jawa Tengah, Kinerja, Vol. 19, No. 2: 97-11.

[BPS Rembang Regency], 2018, Kabuaten Rembang Dalam Angka 2018, ISSN/ISBN: 978-6026886-64-4, Rembang.

[Direktorat Jenderal Bea dan Cukai], 2019, Laporan Pengelolaan DBH CHT Tahun 2018, Kementerian Keuangan Republik Indonesia, Jakarta.

Hapid, H.M. \& Wulandari Y., (2015), Pengaruh Dana Alokasi Khusus, Dana Bagi Hasil, dan Dana Alokasi Umum terhadap APBD Kabupaten Luwu, Jurnal Ekonomi Pembangunan, Vol. 02, No. 01: 1-7.

Hidayati, A., and Kuncoro, M., (2002). Konsentrasi Geografis Industri Manufaktur di Greater Jakarta dan Bandung Periode 1980-2000: Menuju Satu Daerah Aglomerasi?, Empirika, Vol 17, No.2.

Hikmawati, A., (2017), Implementasi Program Pelatihan Ex-Buruh Rokok dari Penggunaan Dana Bagi Hasil Cukai Hasil Tembakau (DBHCHT) Kabupaten Kudus, Jurnal Ilmu Pemerintahan Undip, Vol. 6, No. 4: $n p$.

Juanda, B., (2009), Ekonometrika: Pemodelan dan Pendugaan, Bogor: IPB Press.

Nikijuluw, R., (2012), Analisis Pengaruh Transfer Pemerintah Pusat terhadap Upaya Pemungutan Pajak Kabupaten/Kota di Indonesia, Jurnal Ekonomi dan Pembangunan Indonesia, Vol. 12, No. 2: 168-191.

Pose, A.R., Tjimstra, S.A.R., Bwire, A., (2007). Fiscal Decentralization, Efficiency, and Growth. Department of Geography and Environmental, London School of Economics.

Rasulong, I., (2012), Implikasi Dana Perimbangan terhadap Pertumbuhan Ekonomi dan Dampaknya terhadap Pendapatan Asli Daerah Kabupaten Takalar, Jurnal Ekonomi Balance, Vol. 8, No. 2: 139-157.

Sanjaya, T., (2017), Penerimaan Pemerintah Provinsi Lampung Dari Dana Bagi Hasil Cukai Hasil Tembakau. Jurnal Ilmiah Hukum Administrasi Negara, Vol. 4 No. 2: np. 
Sari, I.M.D.C., (2012), Hubungan Kewenangan Antara Pemerintah Pusat dengan Pemerintah Daerah Dalam Pelaksanaan Program/Kegiatan Alokasi Dana Cukai Hasil Tembakau, Yuridika, Vol. 27, No. 3: 245-266.

Sumarsono, H., (2015), Analisis Pengembangan Wilayah Daerah Malang Utara, JESP Vol. 7, No. 1: 31-45.

Tarigan, R. (2006). Perencanaan Pembangunan Wilayah. Edisi Revisi. Jakarta: Bumi Aksara

World Bank (2010), Dana Transfer Pusat ke Daerah: Penyempurnaan Grand Design Desentralisasi Fiskal, Jakarta. 